\title{
$\mathbb{A}$ Economics Bulletin
}

\section{Volume 41, Issue 1}

\section{Does Informality and Trade Openness Impact Long Run Growth? Empirical Evidence from Ghana}

\author{
Charles K. Mawusi \\ University of Bordeaux
}

\begin{abstract}
Using an Autoregressive Distributed Lag (ARDL) technique, and the Granger causality test, this paper examines the dynamic relationship between economic growth, the size of the informal economy, and trade openness in Ghana. Our results provide evidence of a positive and bidirectional causality between the size of the informal economy and economic growth. Moreover, we find that openness to trade has a significant causal effect on the prevalence of informal activities and economic growth.
\end{abstract}

I would like to thank all the Editor and all the anonymous reviewers for their time and constructive comments. Lastly, I would like to thank Mrs. Amandine Ribot for her assistance and support during the preparation of this manuscript.

Citation: Charles K. Mawusi, (2021) "Does Informality and Trade Openness Impact Long Run Growth? Empirical Evidence from Ghana", Economics Bulletin, Vol. 41 No. 1 pp. 28-40

Contact: Charles K. Mawusi - charles.mawusi@u-bordeaux.fr.

Submitted: January 13, 2020. Published: March 10, 2021. 


\section{Introduction}

Openness to trade and curbing informal economic activities has become a common policy target for many developing economies. This is in part, due to the largely supported notion that trade liberalization stimulates the economy, whereas, informality impedes economic growth. Indeed, conventional theories posit that openness to trade can boost economic growth by facilitating the efficient allocation of resources. Informality, on the other hand, is argued to be characterized by inefficient production and resource misallocation which slows down economic growth. But, recent theories have concluded that the effect of trade openness and informality on economic growth can be both positive and negative, and varies across countries (Zahonogo, 2016; Kim et al., 2012).

A number of studies have attempted to empirically rationalize these theoretical assertions with mixed results. For example, Gries and Redlin (2012), and Liu et al. (2009) find that there exists a positive long-run relationship and bi-directional causality between trade openness and economic growth. In contrast, Polat et al. (2015) and Musila and Yiheyis (2015) find that openness to trade impedes long-run growth. For the informality-growth nexus, previous empirical studies have focused on establishing correlations rather than causation. For instance, Elgin and Birinci (2016) find the size of the informal economy to be positively (negatively) correlated with economic growth in high (low) income economies. Fugazz and Fiess (2010) also find that informality increases with trade liberalization.

With the prevailing ambiguity, this paper contributes to the existing literature by investigating the dynamic relationship between informality, trade openness, and economic growth in Ghana using the Autoregressive Distributed Lag (ARDL) approach. Further, we use the granger causality test to disentangle if causality exists, and then establish the direction of causality.

We focus on the country Ghana for three main reason: (1) The country has undergone major trade reforms over the last three decades, and has become an advocate for free trade across Africa (2) It is one of the fastest-growing economies in the world (3) There is a growing local and international pressure to curb rising informal activities. Thus, findings from this study have significant implications not only for public policy in Ghana but also, for other developing economies with similar challenges and economic structure.

The remainder of this paper is organized as follows: The next section outlines the empirical methodology, and data, followed by a summary of the main findings. The last section contains concluding remarks and policy recommendations. 


\section{Data and empirical methodology}

\subsection{Data}

Our empirical analysis is based on annual data spanning 1980-2014. Data on trade openness and the real GDP growth are obtained from the World Development Indicators database. Data on the size of the informal economy, defined as a percentage of GDP is obtained from the dynamic general equilibrium series by Elgin and Oztunali (2012).

\subsection{The Unit Root Test}

We use the Augmented Dicky Fuller (ADF) and Phillips-Perron tests to investigate the order of integration of the data. These tests suggest under the null hypothesis that a data series of a given variable has unit-roots (non-stationary). The results show that, under both the ADF and PhillipsPerron framework, only the GDP growth data series is consistently stationary at levels (Table 1). But, all the variables are stationary at first difference.

\subsection{The Error Correction Model}

Considering that the variables in this study are I (0) and I (1) processes, we proceed to estimate the long-run relationship using the ARDL bound test proposed by Pesaran et al. (2001). Given that there exists a cointegrating relationship between our variables, we estimate an error correction model. The dynamic unrestricted error correction model for this study can be represented as follows:

$$
\begin{aligned}
& \Delta G D P_{t}=\beta_{01}+\sum_{i=1}^{p} \alpha_{1 i} \Delta G D P_{t-i}+\sum_{i=0}^{q} \alpha_{2 i} \Delta I N F_{t-i}+\sum_{i=0}^{k} \alpha_{3 i} \Delta \operatorname{Trade}_{t-i}+\lambda_{1} E C_{t-1}+\varepsilon_{1 t} \\
& \Delta I N F_{t}=\beta_{02}+\sum_{i=1}^{p} \alpha_{1 i} \Delta I N F_{t-i}+\sum_{i=0}^{q} \alpha_{2 i} \Delta G D P_{t-i}+\sum_{i=0}^{k} \alpha_{3 i} \Delta \operatorname{Trade}_{t-i}+\lambda_{2} E C_{t-1}+\varepsilon_{2 t} \\
& \Delta \text { Trade }_{t}=\beta_{03}+\sum_{i=1}^{p} \alpha_{1 i} \Delta \operatorname{Trade}_{t-i}+\sum_{i=0}^{q} \alpha_{2 i} \Delta G D P_{t-i}+\sum_{i=0}^{k} \alpha_{3 i} \Delta I N F_{t-i}+\lambda_{3} E C_{t-1}+\varepsilon_{3 t}
\end{aligned}
$$

Where $\Delta$ represents the first difference operator, $\varepsilon_{1 t}, \varepsilon_{2 t}$, and $\varepsilon_{3 t}$ denotes the independent and identically distributed error (iid) terms. GDP denotes the growth of real GDP, Trade represents trade openness, and INF represents the size of the informal economy. $E C_{t-1}$ denotes the error correction term which is derived as residuals from bounds test. The coefficient of the error correction term $\lambda$ represents the speed of adjustment to long-run equilibrium. This term is expected to be negative and statistically significant. 


\section{Empirical Results}

\subsection{Bound test for cointegration}

Table 2, presents the results from the ARDL bounds test. The results show that there exists a longrun relationship between GDP growth, trade openness, and informality. That is, the F-statistics exceeds the upper critical bounds at either $1 \%, 5 \%$ or $10 \%$ significance levels.

Table 2: The results of the ARDL cointegration/Bounds test

\begin{tabular}{lcccccccc}
\hline Estimated model & Optimal lags & F-Statistics & $\mathrm{I}(0)$ & $\mathrm{I}(0)$ & $\mathrm{I}(0)$ & $\mathrm{I}(1)$ & $\mathrm{I}(1)$ & $\mathrm{I}(1)$ \\
\hline Critical Values & & & $1 \%$ & $5 \%$ & $10 \%$ & $1 \%$ & $5 \%$ & $10 \%$ \\
\hline GDP INF + Trade & $(1,0,0)^{* * *}$ & 6.288 & 5.15 & 3.79 & 3.17 & 6.36 & 4.85 & 4.14 \\
INF $\sim$ GDP + Trade & $(1,1,1)^{*}$ & 4.702 & 5.15 & 3.79 & 3.17 & 6.36 & 4.85 & 4.14 \\
Trade $\sim \mathrm{INF}+\mathrm{GDP}$ & $(1,0,0)$ & 1.970 & 5.15 & 3.79 & 3.17 & 6.36 & 4.85 & 4.14 \\
\hline
\end{tabular}

$* * * \mathrm{p}<0.01, * * \mathrm{p}<0.05, * \mathrm{p}<0.1$.

\subsection{Long-run and short-run estimates}

The results of the unrestricted dynamic error correction model (ECM) are presented in Table 3. The results confirm the existence of a long-run relationship between trade, the size of the informal economy, and economic growth. As shown on the table, the size of the informal sector has a significant positive impact on economic growth. A $1 \%$ increase in the size in the informal economy is associated with a $1.6 \%$ growth in GDP in the long run. Also, a $1 \%$ growth in the GDP and trade openness is associated with $0.173 \%$ and $0.16 \%$ increases in the size of the informal economy respectively. As expected, the coefficients of the lagged error correction term $\mathrm{EC}_{\mathrm{t}-1}$ are negative and statistically significant at the $1 \%$ level of significance for the two cointegrating vectors. This implies convergence towards long-run equilibrium. Our results did not change when tested with the robust Newey standard errors. A test of stability (cusum and cusumsq) also reveal that the coefficients in the error correction models are stable at the 5\% significance level (see Fig. 1 and Fig. 2 below).

\subsection{Granger causality}

Table 4 presents the results from the Granger causality test. The results indicate that trade openness has an important causal impact on economic growth and the size of the informal economy. The results also show a strong bidirectional causal relationship between economic growth and informality; namely, the size of the informal economy influences economic growth and vice-versa. However, there is no evidence that economic growth and the size of the informal economy causes trade openness. 


\section{Conclusions and policy implications}

There is a growing theoretical and empirical ambiguity on the consequences of trade liberalization and informality especially for developing economies. Using the ARDL-Bounds, and Granger causality tests, this paper examines the long-run relationship and causality between the size of the informal economy, trade openness and economic growth in Ghana. The results show that there exists a long-run relationship between trade openness, economic growth, and informality for the period 1980-2014. The results suggest informality as one of the main forces driving economic performance in Ghana. We also find that in the long run, the size of the informal economy increases with greater openness to trade, and rising economic growth. These findings contradict the popular notion that informality decreases as economies grow. This positive effect of growth on informality highlights a classical case for developing economies where economic growth does not necessarily translate into improving people's standard of living or better employment opportunities.

Further, our results show that openness to trade and the size of the informal economy has a causal effect on economic growth. Likewise, economic growth and trade openness on the size of the informal economy.

Thus, policies aimed at reducing informality could have a detrimental effect on the economy. Moreover, using openness to trade as an instrument to curb informality through standardization may be counterintuitive considering the high level of informality in Ghana. Policymakers should, therefore, take into account the potential counteractive consequences when designing trade and informality reforms, so as to avoid unintended and often detrimental policy shocks. 
Table 3: ARDL Long and Short Run Results

\begin{tabular}{|c|c|c|c|c|}
\hline$\Delta$.GDP & Coef. & Std. Err. & $\mathrm{t}$ & Prob. \\
\hline \multicolumn{5}{|c|}{ Error Correction estimates } \\
\hline Constant & 0.028 & 0.114 & 0.059 & 0.953 \\
\hline$\Delta \mathrm{GDP}_{\mathrm{t}-1}$ & 0.028 & 0.482 & 1.324 & 0.196 \\
\hline$\Delta \mathrm{INF}$ & 0.4322 & 0.706 & 0.6123 & 0.545 \\
\hline$\Delta$ Trade & 0.017 & 0.043 & 0.391 & 0.699 \\
\hline $\mathrm{EC}_{\mathrm{t}-1}$ & -0.934 & 0.222 & -4.196 & $0.00 * * *$ \\
\hline R-squared & 0.42 & & & \\
\hline Adj. R-Squared & 0.33 & & & \\
\hline \multicolumn{5}{|l|}{ GDP } \\
\hline \multicolumn{5}{|c|}{ Long-Run Estimates } \\
\hline constant & -60.828 & 17.144 & -3.548 & $0.00 * * *$ \\
\hline Trade & 0.020 & 0.020 & 0.98 & 0.331 \\
\hline INF & 1.649 & 0.460 & 3.5850 & $0.00 * * *$ \\
\hline R-squared & 0.47 & & & \\
\hline Adj. R-Squared & 0.44 & & & \\
\hline$\Delta . \mathrm{INF}$ & Coef. & Std. Err. & $\mathrm{t}$ & Prob. \\
\hline \multicolumn{5}{|c|}{ Error Correction estimate } \\
\hline Constant & 0.063 & 0.115 & 0.551 & 0.586 \\
\hline$\Delta \mathrm{INF}_{\mathrm{t}-1}$ & 0.041 & 0.171 & 0.224 & 0.809 \\
\hline$\Delta \mathrm{GDP}$ & 0.030 & 0.0366 & 0.8285 & 0.415 \\
\hline$\Delta \mathrm{GDP}_{\mathrm{t}-1}$ & 0.0396 & 0.0388 & 1.0186 & 0.318 \\
\hline$\Delta$ Trade & 0.017 & 0.010 & 1.694 & 0.102 \\
\hline$\Delta \operatorname{Trad}_{\mathrm{t}-1}$ & 0.010 & 0.010 & 1.046 & 0.305 \\
\hline $\mathrm{EC}_{\mathrm{t}-1}$ & -0.482 & 0.1314 & -3.69 & $0.00 * * *$ \\
\hline R-squared & 0.43 & & & \\
\hline Adj. R-Squared & 0.30 & & & \\
\hline \multicolumn{5}{|l|}{ INF } \\
\hline \multicolumn{5}{|l|}{ Long-Run Estimates } \\
\hline Constant & 37.087 & 0.359 & 103.4 & 0.00 \\
\hline GDP & 0.173 & 0.048 & 3.585 & $0.00 * * *$ \\
\hline Trade & 0.016 & 0.006 & 2.586 & $0.01 * * *$ \\
\hline R-squared & 0.55 & & & \\
\hline Adj. R-Squared & 0.52 & & & \\
\hline
\end{tabular}

*** $\mathrm{p}<0.01, * * \mathrm{p}<0.05, * \mathrm{p}<0.1$. 
Table 4: Granger Causality Results

\begin{tabular}{|c|c|c|c|c|c|c|c|}
\hline \multicolumn{4}{|c|}{ Dependent variable } & & \multicolumn{3}{|c|}{ Strong Causality } \\
\hline & \multicolumn{3}{|c|}{$\begin{array}{l}\text { Short-run causal effects } \\
\text { (F-statistics) }\end{array}$} & Long Run t-Stat. & \multicolumn{3}{|c|}{$\begin{array}{l}\text { Joint Short- and Long } \\
\text { Run }\end{array}$} \\
\hline & $\Delta . \mathrm{GDP}$ & $\Delta . \mathrm{INF}$ & $\Delta$. Trade & $\overline{\mathrm{EC}_{\mathrm{t}-1}}$ & $\begin{array}{c}\Delta . \mathrm{GDP} . \\
\mathrm{EC}_{\mathrm{t}-1}\end{array}$ & $\begin{array}{c}\Delta . \mathrm{INF} . \\
\mathrm{EC}_{\mathrm{t}-1}\end{array}$ & $\begin{array}{c}\Delta . \text { Trade. } \\
\mathrm{EC}_{\mathrm{t}-1}\end{array}$ \\
\hline$\Delta . \mathrm{GDP}$ & & $\begin{array}{l}0.256 \\
(0.62)\end{array}$ & $\begin{array}{l}0.129 \\
(0.72)\end{array}$ & $\begin{array}{l}-0.89 \\
(0.00) * * *\end{array}$ & & $\begin{array}{l}7.90 \\
(0.00)^{* * * *}\end{array}$ & $\begin{array}{l}7.25 \\
(0.00)^{* * * *}\end{array}$ \\
\hline$\Delta . \mathrm{INF}$ & $\begin{array}{l}1.037 \\
(0.32)\end{array}$ & & $\begin{array}{l}1.096 \\
(0.31)\end{array}$ & $\begin{array}{l}-0.482 \\
(0.00) * * *\end{array}$ & $\begin{array}{l}7.050 \\
(0.00)^{* * *}\end{array}$ & & $\begin{array}{l}4.95 \\
(0.02)^{* *}\end{array}$ \\
\hline$\Delta$. Trade & $\begin{array}{l}0.166 \\
(0.69)\end{array}$ & $\begin{array}{l}1.428 \\
(0.24)\end{array}$ & & $\begin{array}{l}-0.144 \\
(0.12)\end{array}$ & $\begin{array}{l}1.493 \\
(0.24)\end{array}$ & $\begin{array}{l}2.034 \\
(0.15)\end{array}$ & \\
\hline
\end{tabular}

$\mathrm{P}$ values are in parentheses. $* * * \mathrm{p}<0.01, * * \mathrm{p}<0.05, * \mathrm{p}<0.1$.
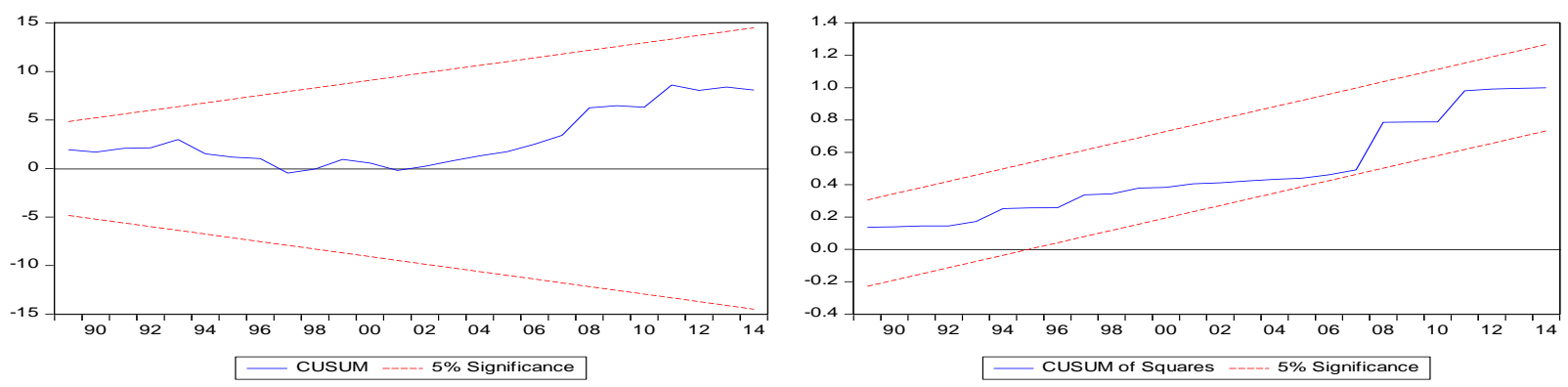

Fig. 1: Cusum and Cusumsq for equation (1)
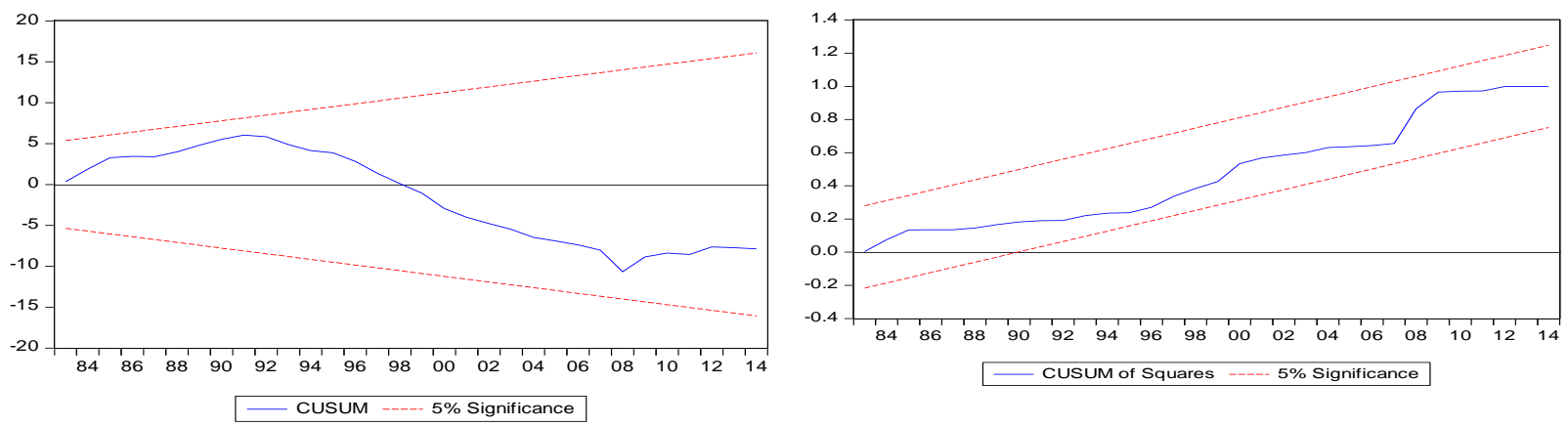

Fig. 2: Cusum and Cusumsq for equation (2) 


\section{References}

Elgin, C., \& Birinci, S. (2016). Growth and informality: a comprehensive panel data analysis. Journal of applied economics, 19(2), 271-292.

Elgin, C., \& Oztunali, O. (2012). Shadow economies around the world: model-based estimates. Bogazici University Department of Economics Working Papers, 5(2012), 1-48.

Fugazza, M., \& Fiess, N. M. (2010). Trade liberalization and informality: new stylized facts. UN Policy Issues in International Trade and Commodities Study Series, (43).

Gries, T., \& Redlin, M. (2012). Trade Openness and Economic Growth: A Panel Causality Analysis. International conferences of RCIE, KIET, and APEA (pp. 16-18). Retrieved from www.C-I-E.org

Kim, D. H., Lin, S. C., \& Suen, Y. B. (2012). The simultaneous evolution of economic growth, financial development, and trade openness. Journal of International Trade and Economic Development, 21(4), 513-537.

Liu, X., Shu, C., \& Sinclair, P. (2009). Trade, foreign direct investment and economic growth in Asian economies. Applied Economics, 41(13), 1603-1612.

Musila, J. W., \& Yiheyis, Z. (2015). The impact of trade openness on growth: The case of Kenya. Journal of Policy Modeling, 37(2), 342-354.

Pesaran, M. H., Shin, Y., \& Smith, R. J. (2001). Bounds testing approaches to the analysis of level relationships. Journal of applied econometrics, 16(3), 289-326.

Polat, A., Shahbaz, M., Rehman, I. U., \& Satti, S. L. (2015). Revisiting linkages between financial development, trade openness and economic growth in South Africa: fresh evidence from combined cointegration test. Quality and Quantity, 49(2), 785-803.

Zahonogo, P. (2016). Trade and economic growth in developing countries: Evidence from subSaharan Africa. Journal of African Trade, 3(1-2), 41-56. 